\title{
Characteristics of pegmatoidal granite exposed near Bayalan, Ajmer district, Rajasthan
}

\author{
Nilanjan Dasgupta ${ }^{1, *}$, Taritwan Pal ${ }^{2}$, Joydeep Sen ${ }^{1}$ and Tamoghno Ghosh ${ }^{1}$ \\ ${ }^{1}$ Department of Geology, Presidency University, 86/1 College Street, Kolkata 700 073, India. \\ ${ }^{2}$ Department of Geology and Geophysics, IIT Kharagpur, Midnapore, West Bengal, India. \\ *e-mail: neelakdg@gmail.com
}

The study involves the characterization of pegmatoidal granite, southeast of Beawar, Ajmer district, Rajasthan. Earlier researchers had described this granite as part of the BGC, basement to the Bhim Group of the Delhi Super Group rocks. However, the present study indicates that it is younger than the rocks of Bhim Group of South Delhi Fold Belt, into which it is intrusive. The intrusion is structurally controlled and the outcrop pattern is phacolithic. The granite had intruded post- $\mathrm{D}_{2}$ deformation of the Delhi orogeny along the axial planes of $\mathrm{D}_{2}$ folds. The intrusion has also resulted in the formation of a contact aureole about the calc gneisses.

\section{Introduction}

A long geological history since Middle Archaean is recorded in the Precambrian belt of Rajasthan. The rocks of the study area fall within the 'Delhi System', defined in the pioneering study of Heron (1953), and now rechristened as the Delhi Supergroup (Gupta and Bose 2000 and references therein) (figure 1). Within the study area around the small village of Bayalan, $10 \mathrm{~km}$ southeast of Beawar in Ajmer district of Rajasthan, pegmatoidal granites have intruded calc-silicate country rocks, which belong to the Mesoproterozoic Delhi fold belt. These folded metasedimentary country rocks belong to the Bhim Group (Gupta et al 1995) of the Delhi Supergroup developed in the eastern flank of the South Delhi Fold Belt (Sinha Roy 1984; Gupta and Bose 2000). The aim of the present study is to elucidate the tectonic evolution of the pegmatoidal granite. A structural map of the pegmatoidal granite intrusive into the calcsilicate gneisses has been prepared and the mineralogical and textural changes brought about in the host rocks by this emplacement have been studied. An attempt is made to fix the time of emplacement with respect to the different deformational events of the Delhi orogeny.

The granites were earlier classified as basement rocks of pre-Delhi age (Heron 1953; Gupta 1934), which is contrary to the present findings.

\section{Lithology}

\subsection{Granite}

\subsubsection{Mode of occurrence}

Granite occurs as massive bodies as well as veins and apophyses intrusive within the calc-silicate rocks. It contains rafts of calc-silicate gneisses ranging in size from one metre to few tens of metres (figure 2). In almost all the cases the granite is emplaced parallel to the gneissic foliation and occurs on the hinges of the folds defined by the gneissosity.

Keywords. Pegmatoidal granite; Bhim Group; South Delhi Fold Belt; phacolith. 


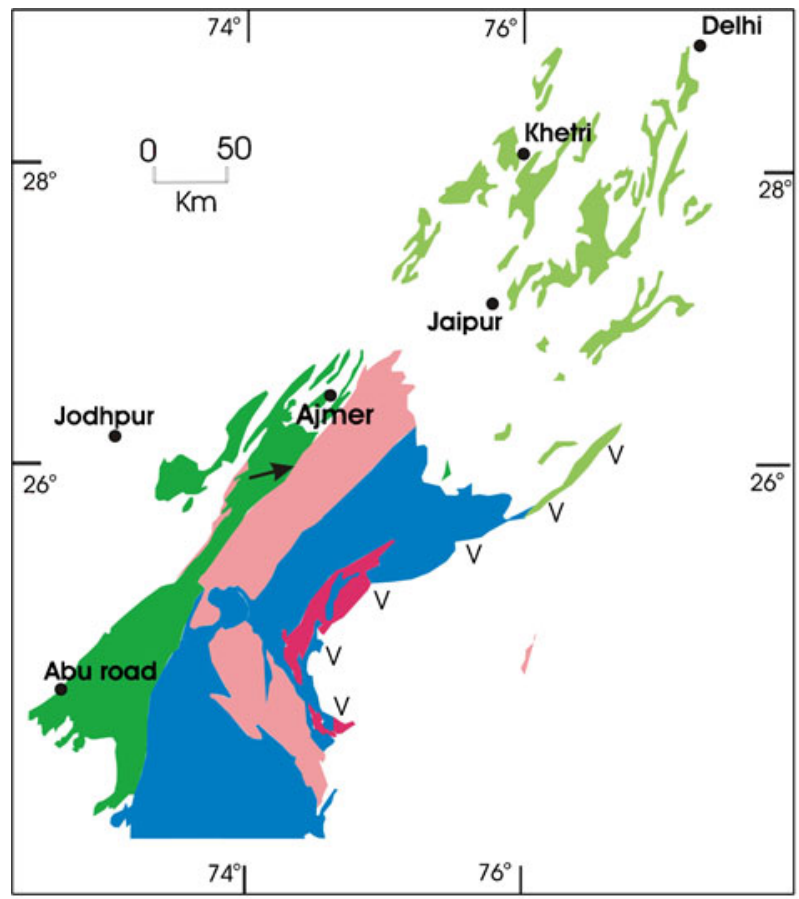

$\square$ North Delhi Fold Belt $\quad \nabla$ Vindhyan Basin $\quad \square$ South Delhi fold belt $\square$ Aravalli Supergroup $\square$ Berach Granite $\square$ Banded Gneissic Complex

Figure 1. Geological map showing the tectono-stratigraphic subdivisions of the Rajasthan craton, redrawn after Heron (1953). The arrow marks the area of study elaborated in figure 2 .

\subsubsection{Petrography}

Most of the granite observed is coarse-to-medium grained; however, coarser-grained pegmatitic varieties are also observed, especially as veins. The pegmatitic granites are the late residual part of the main granite intrusion. The pegmatitic variety shows large crystals of quartz, K-feldspar, plagioclase and thick muscovite-books and thin biotite-clusters. The granite is composed of quartz, microcline, plagioclase, muscovite along with minor occurrences of epidote and sphene.

In thin sections also the coarse-grained inequigranular nature of the granite is visible with a recrystallised fabric though relict hypidiomorphic textures are preserved in small domains within the rock (figure 3a). Often large grains of microcline are surrounded by relatively equidimensional and finer grained quartzo-feldspathic materials, showing a granoblastic texture (figure 3b). Clusters of muscovite occurring interstitially between the larger grains are also observed. A very crude and spaced foliation is defined by these muscovite flakes in the rock. At places, the muscovite grains are kinked (figure 3c). Myrmekitic intergrowth of quartz and K-feldspar is seen implying that a metamorphic event had occurred post-dating the emplacement. Quartz is present as exsolution

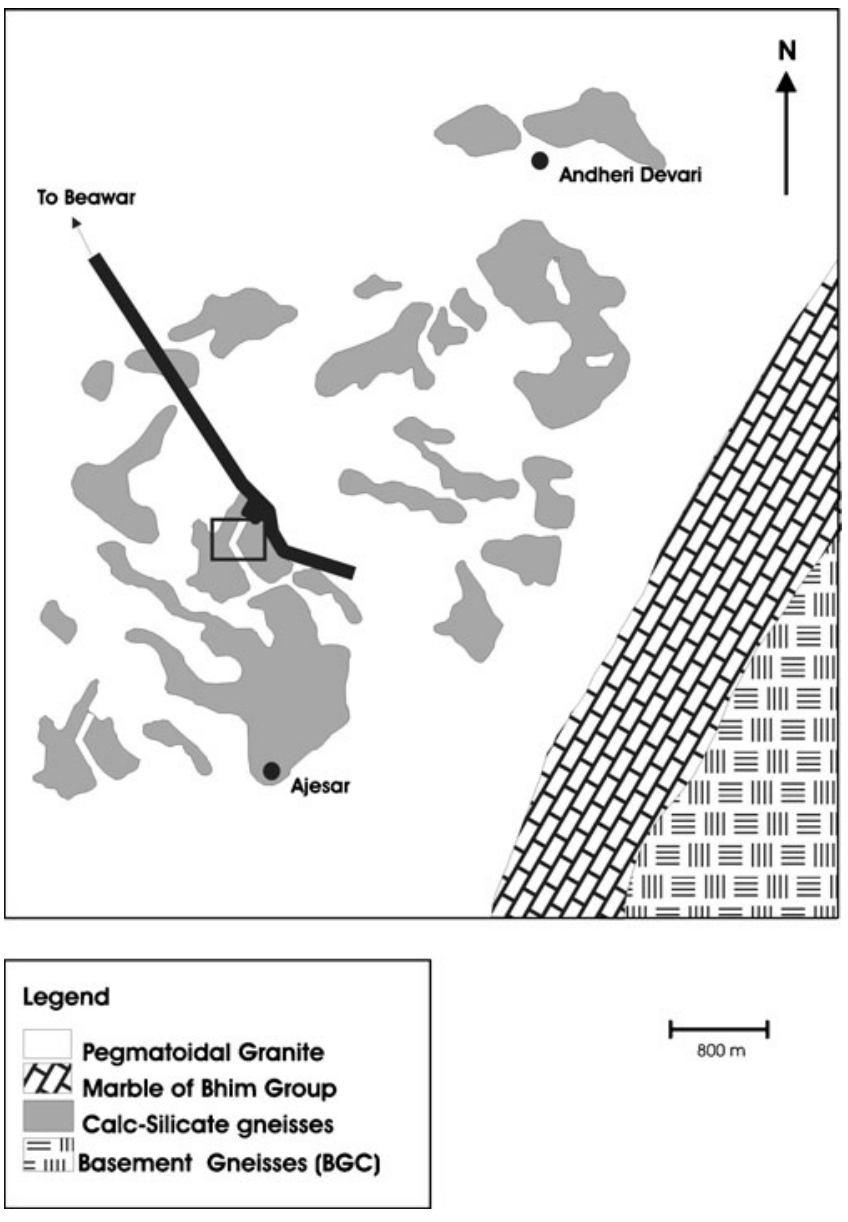

Figure 2. Geological map of the area around Bayalan, showing the enclaves of the calc-silicate gneisses within the pegmatoidal granite exposed in the area. Location of detailed map area of figure 7 is indicated.

lamellae within K-feldspar oriented along the cleavage planes. Garnet occurs as individual grains and also as inclusions within microcline megacrysts (figure 3d). The garnets rarely show compositional zoning and are sometimes retrogressed to biotite along their margin and fracture planes. Slip along twin planes in large microcline grains (figure 3e) is an evidence of intracrystalline deformation. Thus the petrography study indicates that the granite after its emplacement had been subjected to deformation/metamorphism.

\subsection{The calc-silicate gneisses}

\subsubsection{Modes of occurrences}

The calc-silicate gneisses are exposed either as folded bands in the area or as trapezoidal shaped rafts surrounded by granites on all sides. The former occurrence produces a zig-zag shaped 

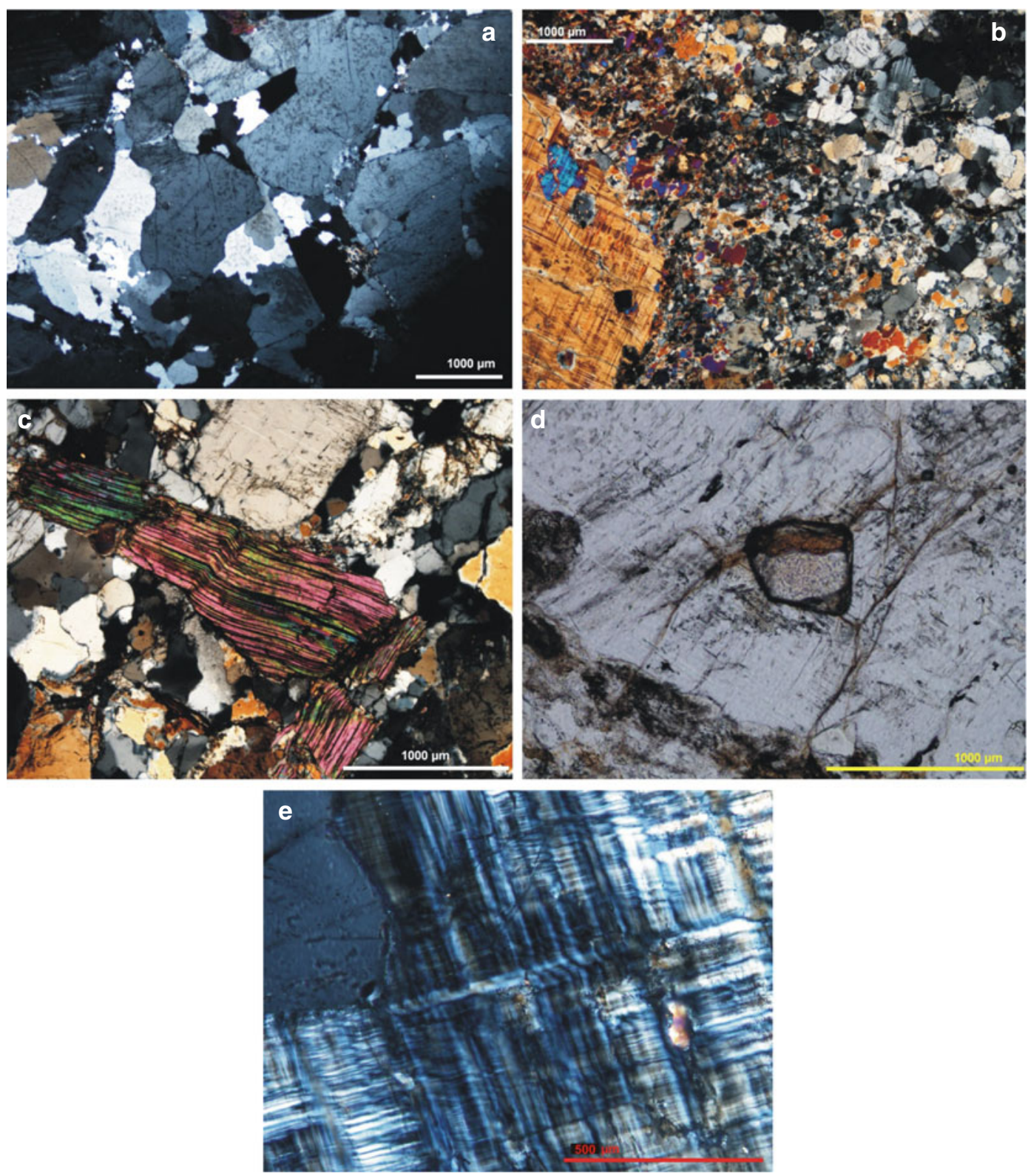

Figure 3. (a) Typically coarse grained inequigranular texture seen within the granite of the area. Granoblastic texture in the rock is indicative of a weak metamorphism. (b) Fine grained corona of quartzo-feldspar around the margin of large crystal of microcline in granite near the contact with calc schists. (c) Kinked muscovite flake in the granite caused by $\mathrm{D}_{3} / \mathrm{D}_{4}$ deformation. (d) Inclusion of garnet within K-feldspar in the granite. This indicates that the K-feldspar must have post-dated the formation of garnet. (e) Kinking of twin lamellae in microcline megacryst.

outcrop pattern and successive such layers with intervening granite produce the typical pinch-andswell outcrop pattern of the rocks of the area (figure 2).

\subsubsection{Petrography}

The calc-silicate gneisses almost everywhere show a prominent set of gneissosity defined by alternate leucocratic and melanocratic bands. The banding is thought to be secondary in nature. The leucocratic bands within the calc-silicate gneisses are composed chiefly of quartz, feldspar, carbonates, epidote, sphene, apatite, zircon with rare occurrences of zoisite (figure 4). The melanocratic bands are made up of hornblende, epidote, biotite, quartz plagioclase, sphene and occasional pyroxene.

\subsection{The contact zone}

Along the contact with the granite, the calc-silicate gneisses have developed thin veneers of baked zone composed of biotite, hornblende, actinolite, 


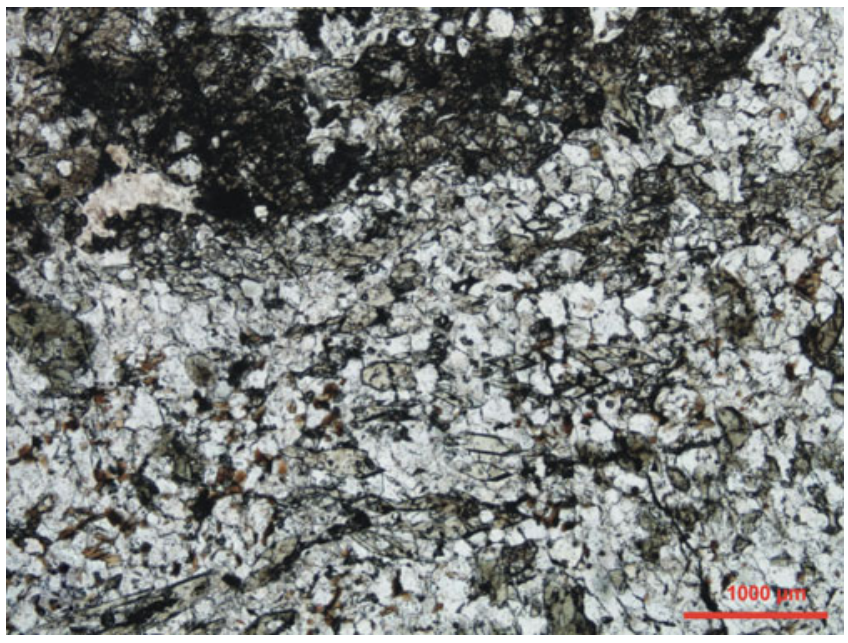

Figure 4. Gneissic banding within calc-silicate gneisses composed of alternate bands of amphibole, biotite, sphene rich layers with bands of quartzo-feldspathic materials.

tremolite, garnet along with quartz and feldspar. Rosettes of actinolite are more abundant than hornblende (figure $5 \mathrm{a}$ and $\mathrm{b}$ ) along with occasional large grains of tremolite (figure $5 \mathrm{a}$ and $\mathrm{b}$ ) indicative of hornfelsic texture (figure $5 \mathrm{c}$ ). Banding is almost absent here; occasionally preserved as relict in a few patches.

Under the microscope one also finds the presence of subidioblastic garnet (figure 5d) surrounded by a fine grained aggregate of quartz and feldspar forming a corona around the garnet grain. Within the corona, the quartz and feldspar define a granoblastic mosaic. Quartzmuscovite simplectite was formed as a contact effect (figure 5e).

\subsection{Field relationship between calc-silicate rocks and granite}

Where the volume of granite is high, the calcsilicates occur as rafts floating in the granite. The size of the calc-silicate rafts vary from less than $1 \mathrm{~m}$ to about $10 \mathrm{~m}$. Where the volume of granite is less than that of the country rocks, it occurs as injections and apophyses within the calc-silicate gneisses (figure 6).

The intrusion of the granite is structurally controlled and it will be discussed later that the granite has been emplaced through conduits parallel to the $\mathrm{D}_{2}$ axial plane of the regional fold pattern. Continuity of structures in the different rafts separated by granite suggests that the latter spread along the folded fissile gneissosity planes, in a sill like manner. Being viscous, the granite accumulated near the hinges give rise to a phacolithic form. This has resulted in the curved outcrop pattern of the bands of granite occurring within the calc-silicate rocks without much of tilting.

\section{Structural geometry}

The lithological map of the area adjoining Bayalan village shows concavo-convex outcrops of calcsilicate gneisses within granite (figure $7 \mathrm{a}, \mathrm{b}$ and $\mathrm{c}$ ). In the area southeast of Bayalan village, several stringers of granite originate from one main conduit and inject the calc-silicate gneisses in a lit-parlit manner. Residence of concordant granite sheets in the hinge region suggest the emplacement to be of phacolithic nature.

The granite is injected into the country rocks without much of a force. The structural fabrics have the same orientation in the isolated rafts, and there is no rotation of the blocks.

\subsection{Deformation sequence}

The calc-silicate gneisses have undergone four phases of deformation, namely $\mathrm{D}_{1}, \mathrm{D}_{2}, \mathrm{D}_{3}$ and $\mathrm{D}_{4}$. The last phase, $\mathrm{D}_{4}$, is not well represented in the area, but for a few foliations measured here and there.

The first phase of folding $\left(\mathrm{D}_{1}\right)$ has produced tight to isoclinal intrafolial folds in the calcsilicate gneisses. These have non-plunging to gently northerly plunging axes with variable plunge directions. $\mathrm{D}_{1}$ has folded a compositional banding which is thought to be primary in nature $\left(\mathrm{S}_{0}\right)$. The corresponding axial planar fabric is a gneissosity $\left(\mathrm{Gn}_{1}\right)$ which is the regionally dominant compositional layering and the original banding is mostly transposed parallel to this secondary fabric (Turner and Weiss 1963; McIntyre 1951; Passchier and Trouw 2000). Therefore the regional gneissosity is a composite fabric.

The second deformation $\left(D_{2}\right)$ has produced mesocsopic folds within the calc-silicate gneisses (figure 8a). These folds are asymmetric, tight to close chevron and are same as folds reported elsewhere from the rocks of the South Delhi Fold Belt (Sengupta 1988; Mukhopadhyay and Matin 1991; Mukhopadhyay and Bhattacharya 2000). These folds are defined by alternate steep and gentle limbs, both dipping northwesterly and have an easterly vergence (figure 8a). The axes of these folds are gently plunging towards either NNE or SSW. A spaced cleavage $\left(\mathrm{S}_{2}\right)$ has developed axial planar to these folds cross cutting the gneissic fabric $\left(\mathrm{Gn}_{1}\right)$ (figure $8 \mathrm{~b}$ ). Superposition 


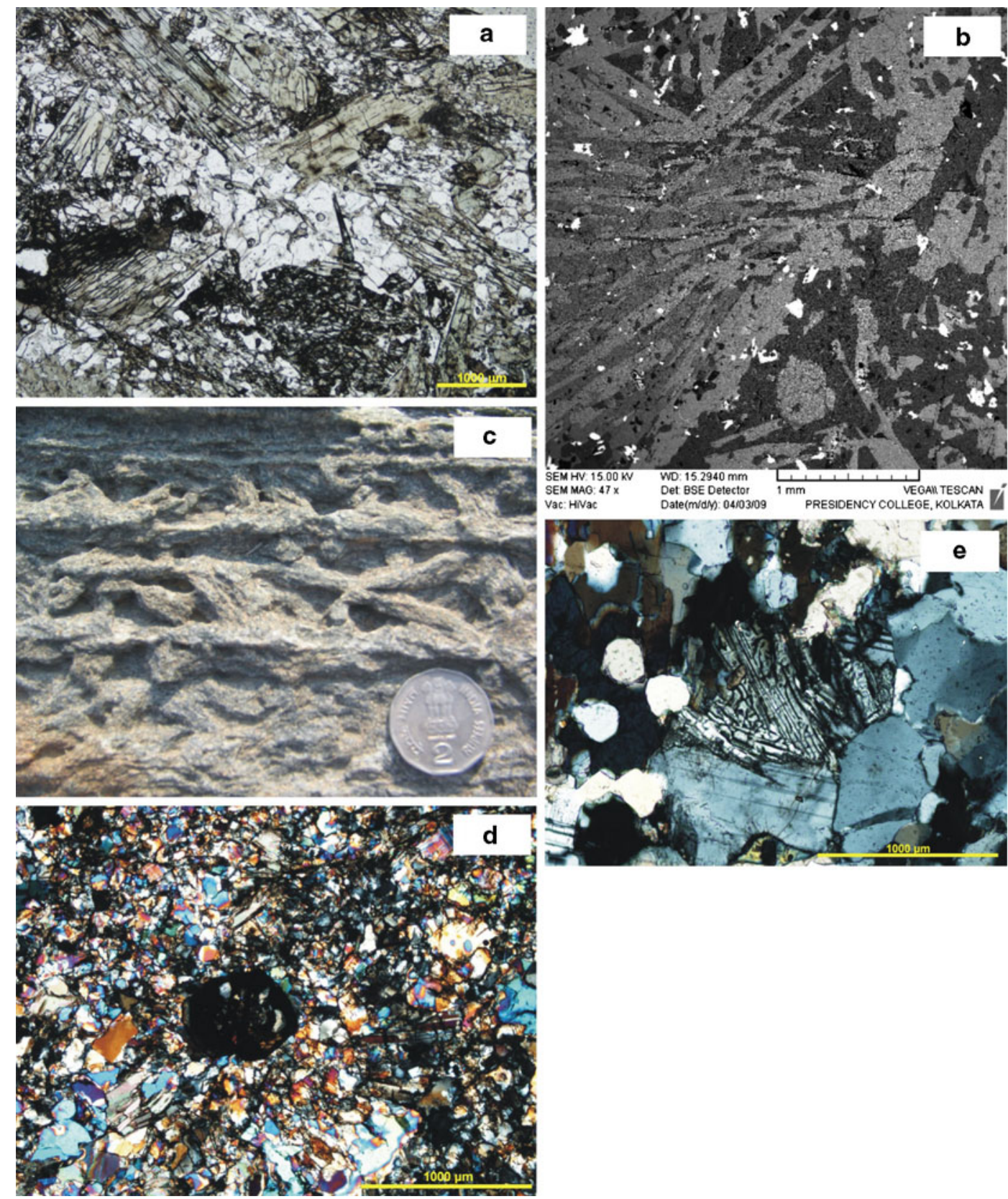

Figure 5. Rosettes of actinolite along with few tremolite grains at the contact regions of the calc-silicate rocks with the granite. (a) Under thin section. (b) Back scatter image of 15a under SEM. (c) Hornfelsic texture developed near the contact zones of calc gneisses with the granite. Note the coarse-grained actinolite needles haphazardly oriented. (d) Subidioblastic garnet seen within the calc-silicate rocks of the contact zone. The garnet is surrounded by quartzofeldspathic grains. A gradual coarsening of grain size is seen radially outward from the garnet. (e) Quartz-muscovite simplectite in calc-silicates at the contact with granite.

of $\mathrm{D}_{2}$ on $\mathrm{D}_{1}$ has produced Type III (hook shaped) interference pattern visible on vertical sections.

The third deformation $\left(\mathrm{D}_{3}\right)$ has produced open to gentle upright folds which have developed on the gentler limbs of the $\mathrm{D}_{2}$ folds within the calc gneisses and schists. The axes of these folds are near parallel to the $\mathrm{D}_{2}$ fold axes and are often undifferentiable in the field. Mineral lineation defined by hornblende has developed parallel to the $\mathrm{D}_{2}$ and $\mathrm{D}_{3}$ axes. A spaced axial planar schistosity $\left(\mathrm{S}_{3}\right)$ is developed during this episode of deformation. It has also produced a weak foliation in granite $\left(\mathrm{FG}_{3}\right)$ parallel to the $S_{3}$ fabric in the calc schists. It is possible that the $\mathrm{D}_{2}$ and $\mathrm{D}_{3}$ could be the early and late parts respectively of the same progressive deformation, a point which is not of our prime concern for this study. A more detailed structural 


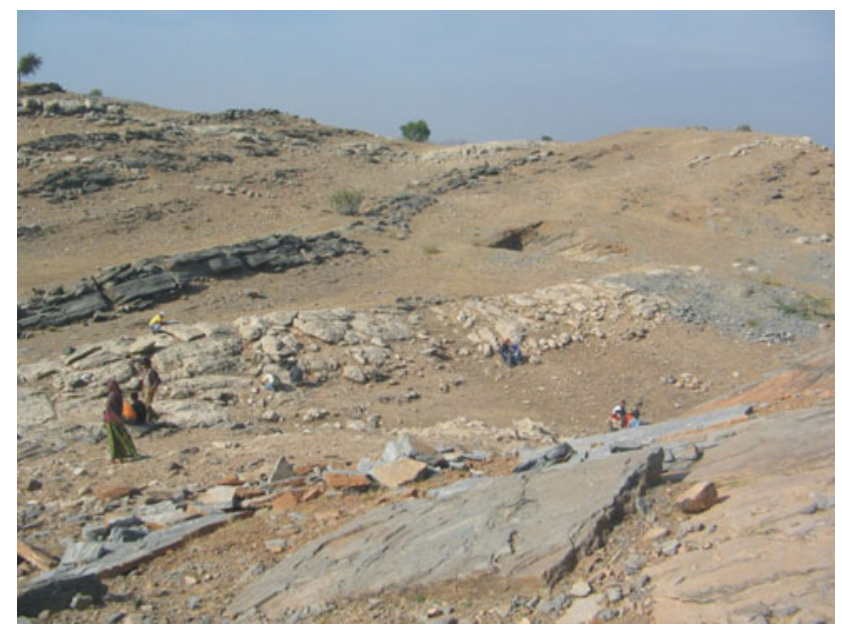

Figure 6. Injection of granite within the layers of calc gneisses in a lit-par-lit manner producing alternate layers of granite and calc gneiss.

analysis of the rocks of the Bhim Group (which have not been intruded by the granite) outside the present study area could possibly resolve the issue.

Post- $\mathrm{D}_{3}$ broad open warping of the axial planar fabric is seen on plan. A foliation within the granite $\left(\mathrm{FG}_{4}\right)$ has been recorded at a few places parallel to the axial planes of the warping.

The analysis of the different structural elements seen within the calc gneisses and granite clearly show that the granites have been affected by $\mathrm{D}_{3}$ and $\mathrm{D}_{4}$. The fact that the granite occurs in the hinge regions of the $\mathrm{D}_{2}$ folds also implies that the injection of the granite must have taken place after $\mathrm{D}_{2}$ deformational episode.

\subsection{Orientation analysis}

Equal area plots of the data were done using the GEORIENT software and the eigenvalues for the distribution were calculated. Based on the eigenvalues, the cones of confidence for 95\% confidence limits were drawn following Bingham's distribution (Woodcock 1977). The data are presented in table 1 . The gneissic banding, which is composite in nature, is folded by $\mathrm{D}_{1}, \mathrm{D}_{2}$ and $\mathrm{D}_{3}$ deformations. Equal area projection of 68 poles to the limbs of the $D_{1}$ folds within the calc gneisses in the area show that they are distributed along a girdle $\left(319^{\circ} / 90^{\circ}\right)$ (table 1$)$. The $\beta$ of the girdle is non-plunging trending $49^{\circ}-229^{\circ}$ (figure 9a).

Equal area projection of 301 poles to schistosity and/or gneissosity planes measured in the calc gneisses and schists over the entire area show that they are distributed along a girdle (table 1 ). The $\beta$ of the girdle is again non-plunging trending $46^{\circ}-226^{\circ}$ (figure $9 \mathrm{~b}$ ). Thus, it is very similar to the axis of the folding of the gneissic banding discussed earlier.

The equal area projection of 62 poles to the $\mathrm{D}_{1}$ axial fabric $\left(\mathrm{Gn}_{1}\right)$ within the calc gneisses are distributed along a girdle (table 1), whose normal $(\beta)$ has an attitude of $8^{\circ}$ towards $37^{\circ}$ (figure $9 \mathrm{c}$ ) correlatable with the fold axis of the $\mathrm{D}_{2}$ folds.

Equal area projection of 84 poles to $\mathrm{S}_{2}$ and $\mathrm{D}_{2}$ axial planes in the calc gneisses and schists shows a point concentration (table 1 ) with a mean orientation of $225^{\circ} / 35^{\circ} \mathrm{NW}$ (figure $9 \mathrm{~d}$ ). Equal area projection of 55 poles to $\mathrm{S}_{3}$ and $\mathrm{D}_{3}$ axial planes in the calc gneisses and schists over the entire area shows a point concentration (table 1) with a mean orientation of $226^{\circ} / 78^{\circ} \mathrm{NW}$ (figure 9e).

Equal area projection of $32 \mathrm{D}_{1}$ axial structures including fold axes and mineral lineation in the calc-silicate gneiss shows that they plunge from near horizontal to moderately steep but in different directions (figure 9f). Equal area projection of 145 lineations (mostly fold axes and intersection/striping lineation of $\mathrm{D}_{2}$ and $\mathrm{D}_{3}$ deformations) in the calc-silicate gneisses also show a spread about a point concentration (table 1 ) with a mean orientation of $26^{\circ}$ towards $36^{\circ}$ (figure $9 \mathrm{~g}$ ). This reflects the nearly coaxial nature of the $D_{2}$ and $D_{3}$ deformations.

Within the granite the foliations related to the $\mathrm{D}_{3}$ and $\mathrm{D}_{4}$ episodes of deformation were plotted. Equal area projection of 39 poles to foliations $\left(\mathrm{FG}_{3}\right)$ shows a cluster (table 1 ) with a mean attitude of foliation $36^{\circ} / 58^{\circ} \mathrm{SE}$ (figure $9 \mathrm{~h}$ ) quite similar to the $\mathrm{S}_{3}$ measured in the calc gneisses (figure 9e). Equal area projection of 16 poles to the foliation in granite related to the $\mathrm{D}_{4}$ deformation episode shows a cluster (table 1 ) with a mean attitude of $255^{\circ} / 58^{\circ} \mathrm{NW}$ (figure $9 \mathrm{i}$ ).

\section{Discussion}

The granites were earlier classified as basement rocks of pre-Delhi age by earlier researchers, which is contrary to the present findings. The intrusion of the granite is structurally controlled and has very little altered the original orientation of the country rocks. It has been injected after $\mathrm{D}_{2}$ deformation episode and emplaced along $\mathrm{D}_{2}$ axial plane, which were the planes of weaknesses. This has resulted in the lit-par-lit injection of the granite within the calc-silicate gneisses. Being viscous, the granite was unable to spread, and accumulated near the hinges giving rise to the phacolithic form. 

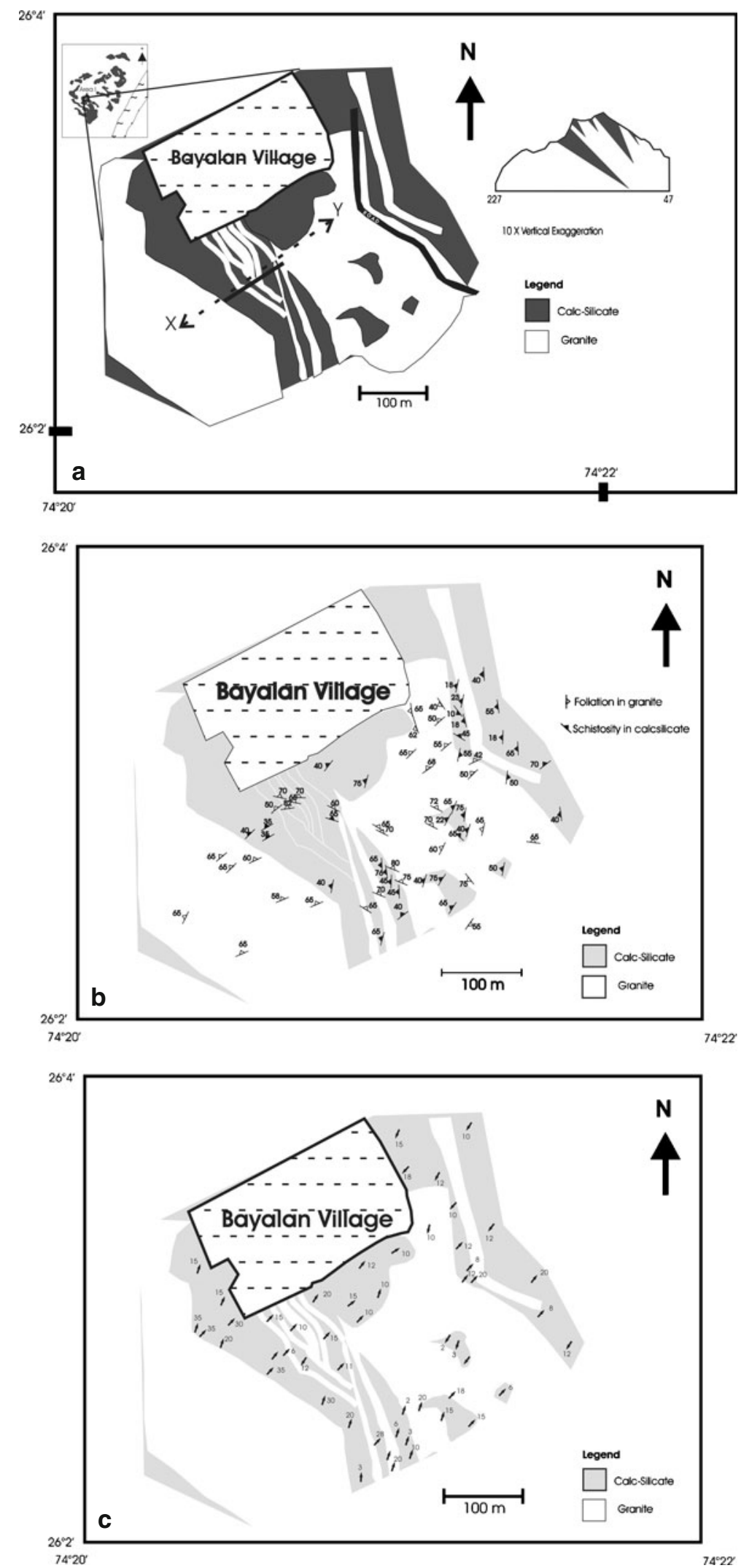

Figure 7. (a) Detailed lithological map of the area adjacent to Bayalan village, $15 \mathrm{~km}$ southeast of Barr. The inset shows the vertical section drawn through XY. (b) Trend map of the planar structural elements of the area around Bayalan. (c) Trend map of the linear structural elements of the area around Bayalan. 

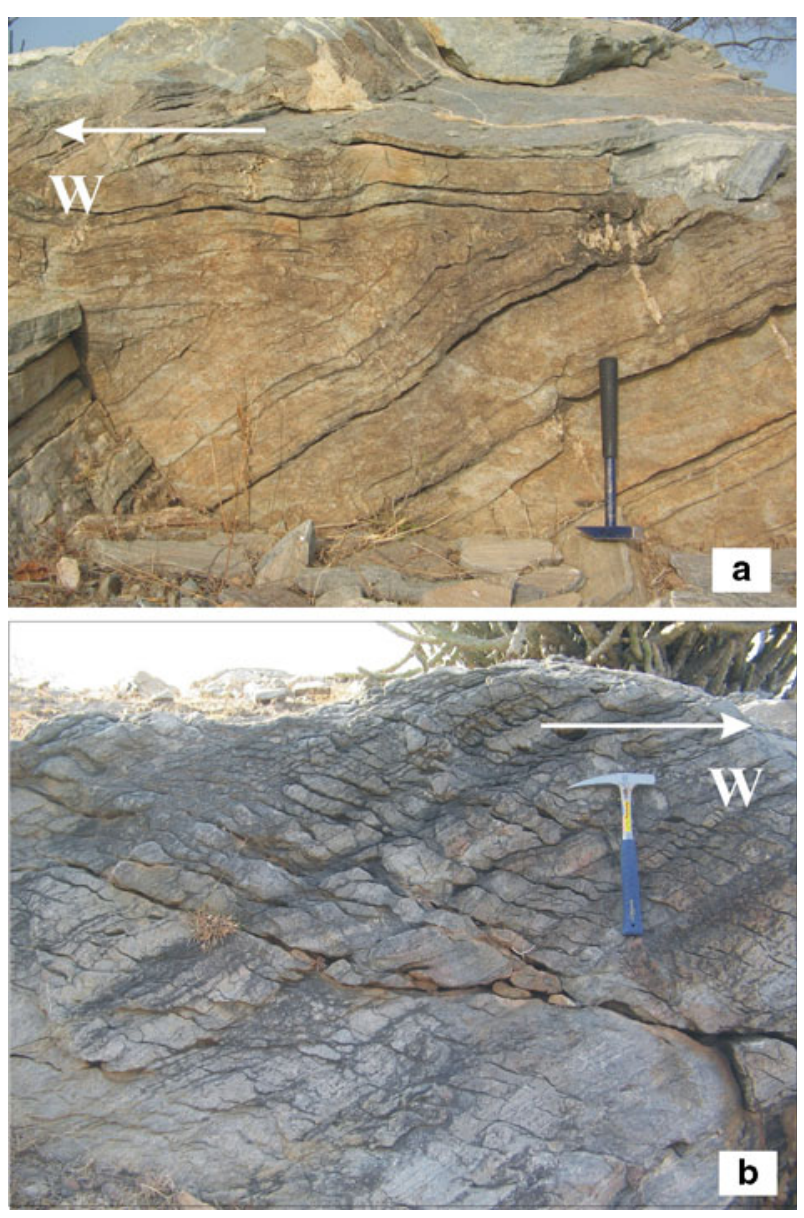

Figure 8. (a) Asymmetric D2 fold with easterly vergence. (b) Gentle westerly dipping spaced D2 cleavage.
The interplay between the lithostatic stress, horizontal stress and tectonic stress results in the formation of different geometry of the pegmatitic bodies. Anderson (1936), Ro Koide and Battacharji (1975), Muller and Pollard (1977), Nakamura et al (1977) and Brisbin (1986) have dwelt upon the formation of fractures and magma emplacement in response to the stresses that develop in the rocks. The present occurrence nearly conforms to the case B of Brisbin (1986) where the injection is controlled by lithostatic pressure combined with directed stress.

This is the only occurrence of granite in the eastern segment of the South Delhi Fold Belt. A proper dating of the granites of the area would be interesting as it would give us the maximum age of the second deformation of the Delhi orogeny. Several bosses and stocks of post-Delhi granite (having an approximate age of $835 \mathrm{Ma}$ as determined by Volpe and Macdougall 1990) have been reported by Gupta et al (1995) and Gangopadhyay and Mukhopadhyay (1984), found mostly in the Sendra Group along the western flank of the South Delhi Fold Belt. According to Volpe and Macdougall (1990) Sm-Nd whole rock isochron age of $1012 \pm 78 \mathrm{Ma}$ of the Ranakpur diorites represents a period of crust formation in the South Delhi Fold Belt. The Sm-Nd mineral isochrons of $838 \pm 36,835 \pm 43,791 \pm 43 \mathrm{Ma}$ for metagabbro, diorite and quartz diorite respectively at Ranakpur point to metamorphic re-equilibration of isotope compositions resulting due to granite and granodiorite emplacement in the Delhi Fold Belt during late-Proterozoic times.

Table 1. Statistical analysis of orientation data.

\begin{tabular}{|c|c|c|c|c|c|c|c|c|}
\hline \multirow[b]{2}{*}{ Type } & \multirow[b]{2}{*}{$\mathrm{N}$} & \multirow[b]{2}{*}{ Nature of distribution } & \multicolumn{3}{|c|}{ Eigenvalues } & \multicolumn{3}{|c|}{$\begin{array}{c}\text { Angular measure of cone of } \\
\text { confidence at } 95 \% \text { level } \\
\text { (measured in degrees) }\end{array}$} \\
\hline & & & $\lambda 1$ & $\lambda 2$ & $\lambda 3$ & $\lambda 1-\lambda 3$ & $\lambda 2-\lambda 3$ & $\lambda 1-\lambda 2$ \\
\hline Limbs of $D_{1}$ folds & 68 & Girdle distribution & 48.144 & 18.632 & 1.224 & 3.60 & 4.69 & - \\
\hline $\begin{array}{l}\text { Poles to schistosity } \\
\text { and/or gneissosity }\end{array}$ & 301 & Girdle distribution & 159.229 & 117.691 & 24.08 & 6.22 & 4.14 & - \\
\hline $\begin{array}{l}\text { Poles to the } \mathrm{D}_{1} \\
\text { axial fabric }\left(\mathrm{Gn}_{1}\right)\end{array}$ & 62 & Girdle distribution & 45.198 & 14.942 & 1.86 & 4.61 & 7.02 & - \\
\hline $\begin{array}{l}\text { Poles to } \mathrm{S}_{2} \text { and } \mathrm{D}_{2} \\
\text { axial planes }\end{array}$ & 84 & Point concentration & 74.508 & 6.804 & 2.688 & 3.14 & - & 3.05 \\
\hline $\begin{array}{l}\text { Poles to } \mathrm{S}_{3} \text { and } \mathrm{D}_{3} \\
\text { axial planes }\end{array}$ & 55 & Point concentration & 41.14 & 8.855 & 5.005 & 7.83 & - & 7.4 \\
\hline $\begin{array}{l}\text { Combined plot of } \\
\mathrm{D}_{2} \text { and } \mathrm{D}_{3} \text { lineations }\end{array}$ & 145 & Point concentration & 107.3 & 31.9 & 5.80 & 3.29 & - & 2.83 \\
\hline $\begin{array}{l}\text { Poles to foliations } \\
\left(\mathrm{FG}_{3}\right)\end{array}$ & 39 & Point concentration & 36.309 & 1.755 & 0.936 & 3.96 & - & 3.91 \\
\hline $\begin{array}{l}\text { Poles to the foliation } \\
\text { in granite related } \\
\text { to } \mathrm{D}_{4}\end{array}$ & 16 & Point concentration & 13.648 & 1.696 & 0.656 & 9.86 & - & 9.45 \\
\hline
\end{tabular}



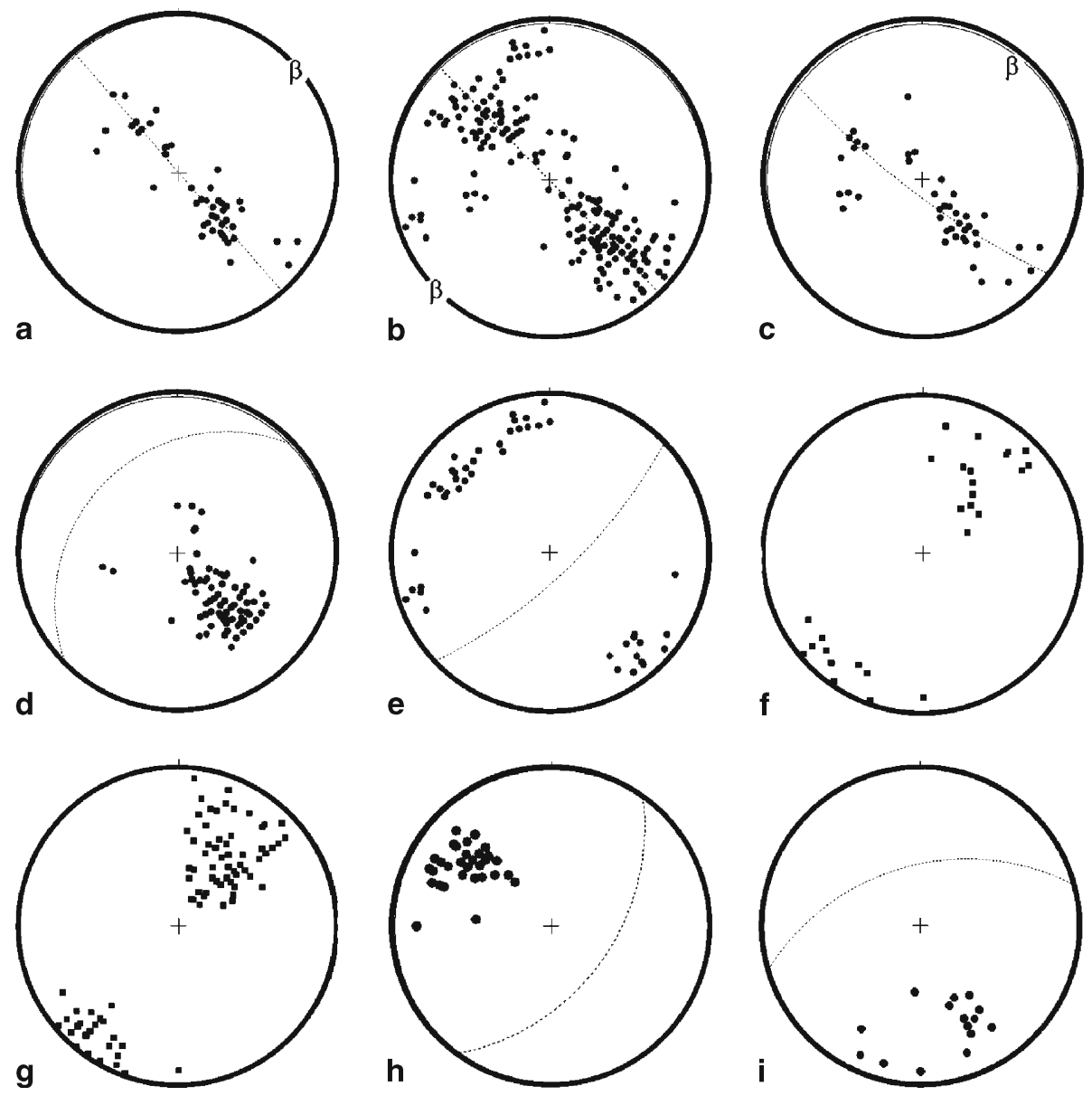

Figure 9. (a) Equal area projections of the different structural elements. Gneissosity of calc gneiss, $\mathrm{N}=68$. (b) Schistosity and/or gneissosity in calc gneiss and schists, $\mathrm{N}=301$. (c) $\mathrm{D}_{1}$ axial planes within the calc gneiss, $\mathrm{N}=62$. (d) $\mathrm{S}_{2}$ and $\mathrm{D}_{2}$ axial planes within the calc gneiss, $\mathrm{N}=84$. (e) $\mathrm{S}_{3}$ and $\mathrm{D}_{3}$ axial planes within the calc gneiss, $\mathrm{N}=55$. (f) Mineral lineation and $\mathrm{D}_{1}$ fold axes, $\mathrm{N}=32$. (g) Fold axes and striping/intersection lineations within the calc gneiss and calc schist, $\mathrm{N}=142$. (h) Foliation planes related to $\mathrm{D}_{3}$ deformation episode in granite, $\mathrm{N}=39$. (i) Foliation planes related to $\mathrm{D}_{4}$ deformation episode in granite, $\mathrm{N}=16$.

\section{Acknowledgement}

ND wishes to acknowledge gratefully the research funding provided by University Grants Commission, (ERO) India, Sanction No. F. PSW - 070/0910 (ERO) dated 08/10/09.

\section{References}

Anderson E M 1936 The dynamics of the formation conesheets, ring dykes, and caldron-subsidence; Roy. Soc. Edinburgh Proc. 56 128-163.

Brisbin W C 1986 Mechanics of pegmatite intrusion; Amer. Min. 71 644-651.

Fareeduddin and Kroner A 1998 Single zircon age constraints on the evolution of the Rajasthan granulite; In: The Indian Precambrian (ed.) B S Paliwal (Jodhpur: Scientific Publishers), pp. 547-556.

Gangopadhyay A and Mukhopadhyay D 1984 Structural geometry of the Delhi supergroup near Sendra, In: Geological evolution of peninsular India (ed.) Saha A K,
Recent Researches in Geology (Delhi: Hindustan Publishing Corporation), pp. 45-60.

Gupta B C 1934 The Geology of Central Mewar; Geol. Surv. India Memoir 65 107-168.

Gupta P and Bose U 2000 An update of the geology of the Delhi Supergroup in Rajasthan; GSI Spec. Publ. 55 287-306.

Gupta P, Fareeduddin, Reddy M S and Mukhopadhyay K 1995 Stratigraphy and structure of Delhi Supergroup of rocks in central part of Aravalli range; Rec. Geol. Surv. India $12012-26$.

Heron A M 1953 The Geology of Central Rajputana; Geol. Surv. India Memoir 79 389p.

Koide H and Battacharji S 1975 Formation of fractures around magmatic intrusions and their role in ore localization; Econ. Geol. 70 781-799.

McIntyre D B 1951 The tectonics of the area between Grantown and Tomintoul (mid-Strathspey); Quart. J. Geol. Soc. London 107 1-22.

Mukhopadhyay D and Bhattacharya T 2000 Crustal evolution and metallogeny in the northwestern Indian shield (ed.) Deb M, Narosa Publ. House, pp. 126-137.

Mukhopadhyay D and Matin A 1991 Early major folds in the Delhi Supergroup around Hatankhera, Ajmer district, Rajasthan; Indian J. Geol. 63 67-74. 
Muller O H and Pollard D D 1977 The stress state near Spanish Peaks, Colorado, determined from a dike pattern; Pure Appl. Geophys. 55 69-86.

Nakamura K, Jacob K H and Davies J N 1977 Volcanoes as possible indicators of tectonic stress orientation - Aleutians and Alaska; Pure Appl. Geophys. 115 $87-112$.

Passchier C W and Trouw R A J 2000 Microtectonics; Springer, 289pp.

Sengupta S 1988 Development of successive sets of structures in a process of continuous deformation: A case study from the Delhi metasediments near Kharwa, Ajmer Dt., Rajasthan, India; Indian J. Earth Sci. 15 116-131.
Sinha Roy S 1984 Precambrian crustal interaction in Rajasthan, NW India; In: Proc. Seminar on Crustal evolution of Indian shield and its bearing on metallogeny; Indian J. Earth Sci. 84-91.

Turner F J and Weiss L E 1963 Structural analysis of metamorphic tectonites; McGraw Hill, 545pp.

Volpe A M and Macdougall J D 1990 Geochemistry and isotope characteristics of mafic (Phulad ophiolite) and related rocks in the Delhi Supergroup, Rajasthan, India: Implications for rifting in the Proterozoic; Precamb. Res. 48 167-191.

Woodcock N H 1977 Specification of fabric shapes using an eigenvalue method; Geol. Soc. America Bull. 88 12311236 . 